\title{
Morphophysiological responses of cowpea to irrigation with saline water and application of bovine biofertilizer
}

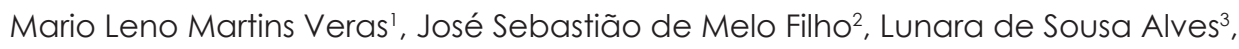
Leandra de Melo Cavalcante Souza ${ }^{4}$, Thiago Jardelino Dias ${ }^{4^{*}}$

\author{
'Federal University of Viçosa, Viçosa, Brazil \\ 2Federal University of Campina Grande, Campina Grande, Brazil \\ ${ }^{3}$ States University of Paraíba, Campina Grande, Brazil \\ ${ }^{4}$ Federal University of Paraíba, João Pessoa, Brazil \\ *Corresponding author, e-mail: thiagojardelinodias@gmail.com
}

\begin{abstract}
Cowpea crop has great economic importance, mainly in the Northeast, where it is a food source for several families. In this context, the objective was to evaluate the effect of levels of electrical conductivity on irrigation water as a function of the application of biofertilizer in the growth and production of cowpea. The experimental design was completely randomized, presenting a factorial scheme of $4 \times 2$, corresponding to four levels of electrical conductivity of the irrigation water (ECW), 1;2;3 and $4 \mathrm{dS} \mathrm{m}^{-1}$ and the presence and absence of bovine biofertilizer application in four replicates. Plant height, number of leaves, stem diameter, number of lateral branches, main branch length, root dry weight, shoot and total number, pod number per plant, mass dry weight of the pod, the length and mean diameter of the pod, the number of grains per plant, the number of grains per pod, the mass of grains and the mass of 100 grains. The increase of ECW inhibits vegetative and productive growth of cowpea and the use of enriched bovine biofertilizer attenuates the effects of saline stress on cowpea, favoring its development.
\end{abstract}

Keywords: Vigna unguiculata L., electrical conductivity, organic input

\section{Introduction}

Cowpea, string bean or macassar bean (Vigna unguiculata (L.) Walp.) Is one of the most important crops in Brazil, since it is a daily food source for most Brazilian families, especially inhabitants of the North and Northeast regions, as well as in African and Asian countries (Teófilo et al., 2008).

One of the alternatives to increase bean productivity is water supply through irrigation, however, one of the factors that must also be taken into account is the quality of the water to be used. Among the characteristics that define water quality for irrigation is the concentration of salts (salinity) that is one of the abiotic factors that restrict plant growth, development and productivity worldwide (Freire et al., 2010; Freire et al., 2011).

Recent studies have shown that salinity inhibits plant development as a consequence of physiological changes, such as growth and yield of the crop (Bezerra et al., 2010; Silva et al., 2013). Oliveira et al. (2013) in cv. "Quarentinha" and Oliveira et al. (2015) studying the effect of salinity on water and biostimulant on cowpea $c v$. Carnaubais have observed that salinity levels above $3.5 \mathrm{dS} \mathrm{m}^{-1}$ severely reduce crop growth and yield.

In order to attenuate the effect of 
saline stress, as one of the alternatives, has been suggested the use of organic inputs, among them the biofertilizer, which besides being used as a soil fertilizer, is also a pest and disease control agent (Pereira et al., 2012). However, it has been used more frequently in agriculture as an alternative method for the attenuation of saline effects (Medeiros et al., 2011; Freire et al., 2014).

The bovine biofertilizer has a positive action on improving soil quality in terms of aeration, besides supplying nutrients and organic matter to the plants. The biofertilizer also contains many beneficial substances, among them, the humic substances which promote the reduction of the osmotic potential of the soil solution, stimulating the absorption of water and nutrients by plants in saline environments.

Silva et al. (2013) and Silva et al. (2011) verified that the increase in the saline content of the waters impaired the initial growth of cowpea, with less intensity in the soil where the bovine biofertilizer was applied. In other crops, Medeiros et al. (2011) and Sousa et al. (2012) also found beneficial effects of bovine biofertilizer in saline mean on cherry, corn and tomato plants.

In this direction, the objective of this work was to evaluate the growth and production of cowpea under the effect of different electrical conductivities of the irrigation water associated to the absence and presence of the bovine biofertilizer.

\section{Material and methods}

The experiment was carried out from September to December 2015 at the Center of Human and Agrarian Sciences in the Department of Agrarian and Exact Sciences of the State University of Paraíba (UEPB) in the municipality of Catolé do Rocha-PB $16^{\circ} 20^{\prime} 38$ " S; $37^{\circ} 44^{\prime} 48$ "W) with 275 altitude meters. The climate of the municipality is of the type BSW ', according to the Köppen classification, that is to say, warm and dry like steppe type, with average monthly temperature superior to $18^{\circ} \mathrm{C}$, throughout the year.

The experimental design was completely randomized (DIC) presenting a factorial scheme of $4 \times 2$, with 4 replicates. The treatments consisted of the combination of the factors: electrical conductivity, water irrigation (ECW) of 1;2;3 and $4 \mathrm{dS} \mathrm{m}^{-1}$ and bovine biofertilizer application, by comparing absence and presence. The experimental units were two bean plants cultivated in pots with the capacity of $15 \mathrm{dm}^{3}$.

The irrigation water had electrical

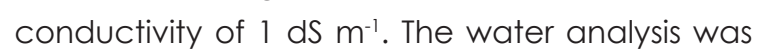
performed and showed the following chemical characteristics: $\mathrm{pH}\left(\mathrm{H}_{2} \mathrm{O}\right)=7.53 ; \mathrm{Ca}^{+2}=2.30 \mathrm{cmolc}$ $\mathrm{dm}^{-3} ; \mathrm{Mg}^{+2}=1.56 \mathrm{cmolc} \mathrm{dm}^{-3} ; \mathrm{Na}^{+}=4.00 \mathrm{cmolc}$ $\mathrm{dm}^{-3} ; \mathrm{K}^{+}=0.02 \mathrm{cmolc} \mathrm{dm}^{-3} ;$ Chloride $=3.90 \mathrm{cmolc}$ $\mathrm{dm}^{-3}$; Carbonate $=0.57 \mathrm{cmolc} \mathrm{dm}^{-3} ;$ Bicarbonate $=3.85 \mathrm{cmolc} \mathrm{dm}^{-3} ;$ RAS $=2.88\left(\mathrm{mmol}_{\mathrm{c}}^{-1}\right)^{1 / 2}$.

A soil classified as Flossic Neosol was used having a sandy loam texture. Samples were collected in the 0 to $20 \mathrm{~cm}$ layer in a native area located on the UEPB campus. From the soil sample used to fill the polyethylene pots, a subsample was taken to be chemically analyzed, which presented the following characteristics: $\mathrm{pH}\left(\mathrm{H}_{2} \mathrm{O}\right)=5.02 ; \mathrm{Ca}^{+2}=4.63 \mathrm{cmolc} \mathrm{dm}^{-3} ; \mathrm{Mg}^{+2}$ $=2.39 \mathrm{cmolc} \mathrm{dm}^{-3} ; \mathrm{Na}^{+}=0.30 \mathrm{cmolc} \mathrm{dm}^{-3} ; \mathrm{K}^{+}=$

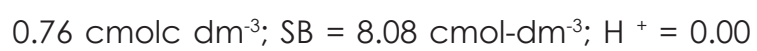
cmolc dm ${ }^{-3} ; \mathrm{Al}^{+3}=0.00 \mathrm{cmolc} \mathrm{dm}^{-3} ; \mathrm{CTC}=8.08$ and Organic matter $=1.88 \mathrm{~g} \mathrm{~kg}^{-1}$.

The bovine biofertilizer was obtained by anaerobic fermentation, that is, in a hermetically sealed environment. To release the methane gas at the top of each biodigester one end of a thin hose was coupled and the other end was immersed in a vessel with water. For the preparation of the biofertilizer, $70 \mathrm{~kg}$ of bovine manure from lactating cows and 120 liters of water were used, adding $5 \mathrm{~kg}$ of sugar and 5 liters of milk aim to accelerate the metabolism of the bacteria.

The biofertilizer was applied 15 days after emergence in $10 \%$ the volume of the pots, and later in the interval of 15 days more applications was made until 6 times was complete. Prior to application, the biofertilizer was subjected to the screen filtration process in order to reduce obstruction risks of the sprinkler screen holes. The biofertilizer was analyzed and presented the following chemical characteristics (Table 1):

The different levels of electrical conductivity of water ( $E C W$ ) were obtained by the addition of sodium chloride $(\mathrm{NaCl})$ to the water from the local supply system, according to 
Table 1. Chemical attributes of the liquid biofertilizer used in the experiment. Catolé do Rocha - PB, UEPB, 2015.

\begin{tabular}{lc}
\hline Chemical Attributes & Values obtained \\
\hline $\mathrm{pH}$ & 4.68 \\
$\left.\mathrm{EC}(\mathrm{dS} \mathrm{m})^{-1}\right)$ & 4.70 \\
Nitrogen (\%) & 1.00 \\
Phosphor $\left(\mathrm{mg} \mathrm{dm}^{-3}\right)$ & 296.20 \\
Potassium $\left(\mathrm{cmol}_{\mathrm{c}} \mathrm{dm}^{-3}\right)$ & 0.71 \\
Calcium $\left(\mathrm{cmol}_{\mathrm{c}} \mathrm{dm}^{-3}\right)$ & 3.75 \\
Magnesium $\left(\mathrm{cmol}_{\mathrm{c}} \mathrm{dm}^{-3}\right)$ & 3.30 \\
Sodium $\left(\mathrm{cmol}_{\mathrm{c}} \mathrm{dm}^{-3}\right)$ & 1.14 \\
Sulfur $\left(\mathrm{cmol}_{c} \mathrm{dm}^{-3}\right)$ & 14.45 \\
\hline
\end{tabular}

Rhoades et al. (2000) since that the quantity of salts $(Q)$ was determined by the equation: $Q$ (mg/ $\left.\mathrm{L}^{-1}\right)=\mathrm{ECW} \times$ 640. In which, ECW $\left(\mathrm{dS} \mathrm{m}^{-1}\right)$ represents the desired value of the electrical conductivity of the water. The water that was chosen as control - S1 (1 dS $\mathrm{m}^{-1}$ ) comes from an amazon well, located near the experimental area of the UEPB. The treatments with the different electrical conductivities of irrigation water began at 15 days after emergence and until harvest.

seeding was carried out directly in the pots, and four BRS Pajéu cowpea seeds were sown for each experimental unit. At 20 days after sowing, the thinning of the seedlings was performed keeping only the most vigorous seedling.

The following characters were evaluated in the vegetative stage $V 9$ at 60 days after emergence (DAE): height of the plant with the aid of a measuring tape graduated in $\mathrm{cm}$, the number of leaves, that was obtained by counting, stem diameter, with a pachymeter digital two $\mathrm{cm}$ above the lap of the plant. The number of lateral branches through counting. Main branch length measured with a graduated ruler.

The dry mass of the root and aerial part, after remaining for approximately 48 hours in a greenhouse of forced air circulation at a temperature of $60^{\circ} \mathrm{C}$ until a constant weight was obtained was weighed in a $0.00001 \mathrm{~g}$ precision scale. The total dry mass was obtained by adding all the dried parts of the plant (stem, leaf and root).

On the occasion of the harvest, at 90 DAE, when the plants were in phase R5 (pods with developed grains and harvest stage), two plants of each plot were collected and evaluated the following characteristics: number of pods per plant, that was obtained by counting it in each plant. The pods were then threshed, measured and weighed to obtain the dry mass of the pod, the length and mean diameter of the pod, number of grains per plant, number of grains per pod, the mass of grains and mass of 100 grains.

Data were submitted to analysis of variance by the "F"test and, in case of significance, the regression analysis was performed using the statistical software SISVAR 5.0. (Ferreira, 2011).

\section{Results and discussion}

The analysis of variance revealed that there was an interaction between the electrical conductivity factors of irrigation water and the bovine biofertilizer for the most of the analyzed variables. There was no significant effect in the interaction between the factors such as stem diameter, number of leaves, total dry mass, dry mass of pods, dry mass of grains and the number of grains per pod. About the isolated effect of the electrical conductivity levels in the irrigation water, there was a significant effect in all variables analyzed. Regarding the isolated effect of the biofertilizer, there were significant responses in all analyzed variables, except for stem diameter and number of grains per plant (Table 2).

Figure 1A presents the results obtained for plant height as a function of ECW increase in cowpea plants treated with bovine biofertilizer. There was a linear response decreasing to ECW increase, with higher values occurring in

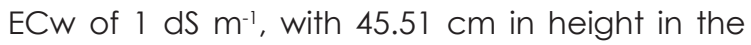
presence of biofertilizer. When the plants were submitted to the conductivity of $4 \mathrm{dS} \mathrm{m}^{-1}$, there was a reduction in plant height, even under the presence of biofertilizer, with values of $34.88 \mathrm{~cm}$ under application of biofertilizer.

Oliveira et al. (2013) studying the interaction between salinity and biostimulant in 
Table 2: Variance analysis (mean squares) of the data referring to plant height (PH), the diameter of the stem (SD), number of leaves (NL), number of lateral branches (NLB), length of the main branch (LMB), dry mass of the root (DMR), dry shoot mass (DSM), total dry mass (TDM), number of pods per plant (NPP), number of grains per plant (NGP), dry mass of pods (DMP), the average length of pods (ALP), the diameter of pods (DP), grain mass (GM), number of grains per pod (NGP) and mass of 100 grains (M100G) of cowpea under effect of different electrical conductivities of irrigation water due to the application of biofertilizer.

\begin{tabular}{|c|c|c|c|c|c|}
\hline Source of Variation & $\mathrm{DF}$ & & Medium & Squares & \\
\hline & & $\mathrm{PH}$ & SD & LF & NLB \\
\hline Electric conductivity & 3 & $232.04^{* *}$ & $47.88^{*}$ & $246.65^{* *}$ & $26.78^{* *}$ \\
\hline Biofertilizer & 1 & $219.45^{* *}$ & $67.83^{\text {ns }}$ & $86.13^{*}$ & $2.53^{*}$ \\
\hline$C \times B$ & 3 & $42.19^{* *}$ & $4.20^{\mathrm{ns}}$ & $22.63^{\text {ns }}$ & $3.69 *$ \\
\hline Residue & 24 & 9.58 & 7.63 & 16.38 & 0.40 \\
\hline \multirow[t]{2}{*}{ CV (\%) } & - & 8.09 & 36.44 & 13.47 & 24.57 \\
\hline & & LMB & DMR & DSM & TDM \\
\hline Electric conductivity & 3 & $485.22^{* *}$ & $68.16^{* *}$ & $536.89 * *$ & $5217.38^{*}$ \\
\hline Biofertilizer & 1 & $637.24^{* *}$ & $44.62^{* *}$ & $578.68 * *$ & $5136.16^{*}$ \\
\hline$C \times B$ & 3 & $154.52 * *$ & $10.35^{* *}$ & $113.79 *$ & $1171.96^{\mathrm{ns}}$ \\
\hline Residue & 24 & 8.13 & 0.77 & 17.95 & 520.56 \\
\hline \multirow[t]{2}{*}{ CV (\%) } & - & 6.68 & 13.79 & 13.22 & 15.20 \\
\hline & & NPP & NGP & DMP & ALP \\
\hline Electric conductivity & 3 & $43.36^{* *}$ & $1649.48^{* *}$ & $43.42^{* *}$ & $54.81^{* *}$ \\
\hline Biofertilizer & 1 & $270.28^{* *}$ & $727.71^{\mathrm{ns}}$ & $208.53^{* *}$ & $275.53^{* *}$ \\
\hline$C \times B$ & 3 & 7.78* & 173.05* & $1.73^{\text {ns }}$ & $6.65^{*}$ \\
\hline Residue & 24 & 1.28 & 47.42 & 0.95 & 1.18 \\
\hline \multirow[t]{2}{*}{ CV (\%) } & - & 19.79 & 21.10 & 19.07 & 10.25 \\
\hline & & $\mathrm{DP}$ & GM & NGP & M100G \\
\hline Electric conductivity & 3 & $19.18^{* *}$ & $181.46^{* *}$ & $53.03^{* *}$ & $1523.28^{* *}$ \\
\hline Biofertilizer & 1 & $182.30^{* *}$ & $268.88^{* *}$ & $63.28^{* *}$ & $1216.97^{* *}$ \\
\hline$C \times B$ & 3 & $2.66^{* *}$ & $2.95^{\mathrm{ns}}$ & $5.69^{\mathrm{ns}}$ & 57.90* \\
\hline Resíduo & 24 & 0.24 & 9.11 & 1.09 & 6.64 \\
\hline CV (\%) & - & 8.98 & 21.25 & 19.34 & 11.86 \\
\hline
\end{tabular}

cowpea cv. "Quarentinha" observed that the height of the plant was negatively affected by salinity in irrigation water. Coelho et al. (2013) in cowpea cv. Pele de moça noticed that the height of the plant was negatively affected by salinity. Working in a saline environment with cowpea, Calvet et al. (2013) also found a reduction in the height of the cowpea $\mathrm{cV}$. EPACE 10.

In the Figure 1B are presented the effect of the different ECW of irrigation on the diameter of the stem where a decreasing linear response can be verified, in which the highest value for stem diameter occurred in the conductivity of $1 \mathrm{dS} \mathrm{m}^{-1}(11 \mathrm{~mm})$. Similar results were observed by Silva et al. (2009), when they submitted the cultivar "Quarentinha" of cowpea to the level of salinity $3,5 \mathrm{dS} \mathrm{m}^{-1}$.

Cowpea plants irrigated with low ECW water presented higher growth in the number of lateral branches (Figure 1C) when compared to those irrigated with water of higher salinity, even with the application of bovine biofertilizer. Analyzing the number of lateral branches as a function of ECW for the application of biofertilizer, it was verified that in low salinity conditions, the plants presented a number of lateral branches of 6.5, when it was irrigated with water of $1 \mathrm{dS}$ $\mathrm{m}^{-1}$. On the other hand, under salinity water of 4 $\mathrm{dS} \mathrm{m}^{-1}$, the number of lateral branches obtained an average of 4 lateral branches with the application of biofertilizer.

In relation to the main branch length, the results showed that there was a linear decreasing effect of ECW, with higher values occurring in the salinity of $1 \mathrm{dS} \mathrm{m}^{-1}$, obtaining averages of $60.73 \mathrm{~cm}$ (with the application of biofertilizer) and $44.9 \mathrm{~cm}$ (without application of biofertilizer) (Figure 1D). Figure 3B shows that ECW highs caused reductions in main branch length so that the lowest values were obtained at the highest salinity $\left(4 \mathrm{dS} \mathrm{m} \mathrm{m}^{-1}\right)$, with $36.37 \mathrm{~cm}$ with biofertilizer and $27.3 \mathrm{~cm}$ without biofertilizer.

The similar negative effect was observed 
by Hadi et al. (2012) when evaluating the response of cowpea to water salinity and observed that irrigation with saline water impaired the length of the main stem.

It is observed in Figure 1E that there was a negative relationship between ECW and root dry mass, even under the application of biofertilizer. For the application of biofertilizer, cowpea plants presented $12.87 \mathrm{~g}$ in the less saline treatment 11 $\mathrm{dS} \mathrm{m}^{-1}$ ) whereas in the more saline $\left(4 \mathrm{dS} \mathrm{m}^{-1}\right)$ the plants produced only $7.65 \mathrm{~g}$. Similar behavior was observed without the application of biofertilizer, in which there was a reduction in root dry mass when the control treatment $\left(1 \mathrm{dS} \mathrm{m}^{-1}\right)$ was compared with the treatment with higher ECW (4 $\mathrm{dS} \mathrm{m}^{-1}$ ).

The effect of salinity on the root dry mass of the cowpea has been reported by several authors (Çiftçi et al., 2011; Almeida et al., 2012, Calvet et al., 2013), where they observed a reduction according to the unit increase in the electrical conductivity.

The relationship between the irrigation water salinity and the dry mass of the aerial part of the cowpea is presented in Figure $1 \mathrm{~F}$, in both biofertilizer conditions, with and without, there was a decreasing linear response of the water electrical conductivity. There was a negative influence of the ECW on the dry mass of the aerial part, as the ECW increased, there was a reduction in the dry mass of the aerial part even under the application of biofertilizer, however, in the plants treated with biofertilizer there was a superiority in the values obtained, with a mean of $51.41 \mathrm{~g}$ and $27.91 \mathrm{~g}$ in the plants irrigated with low $\left(1 \mathrm{dS} \mathrm{\textrm {m } ^ { - 1 } )}\right.$ and high $\left(4 \mathrm{dS} \mathrm{m}^{-1}\right)$ salinity, respectively.
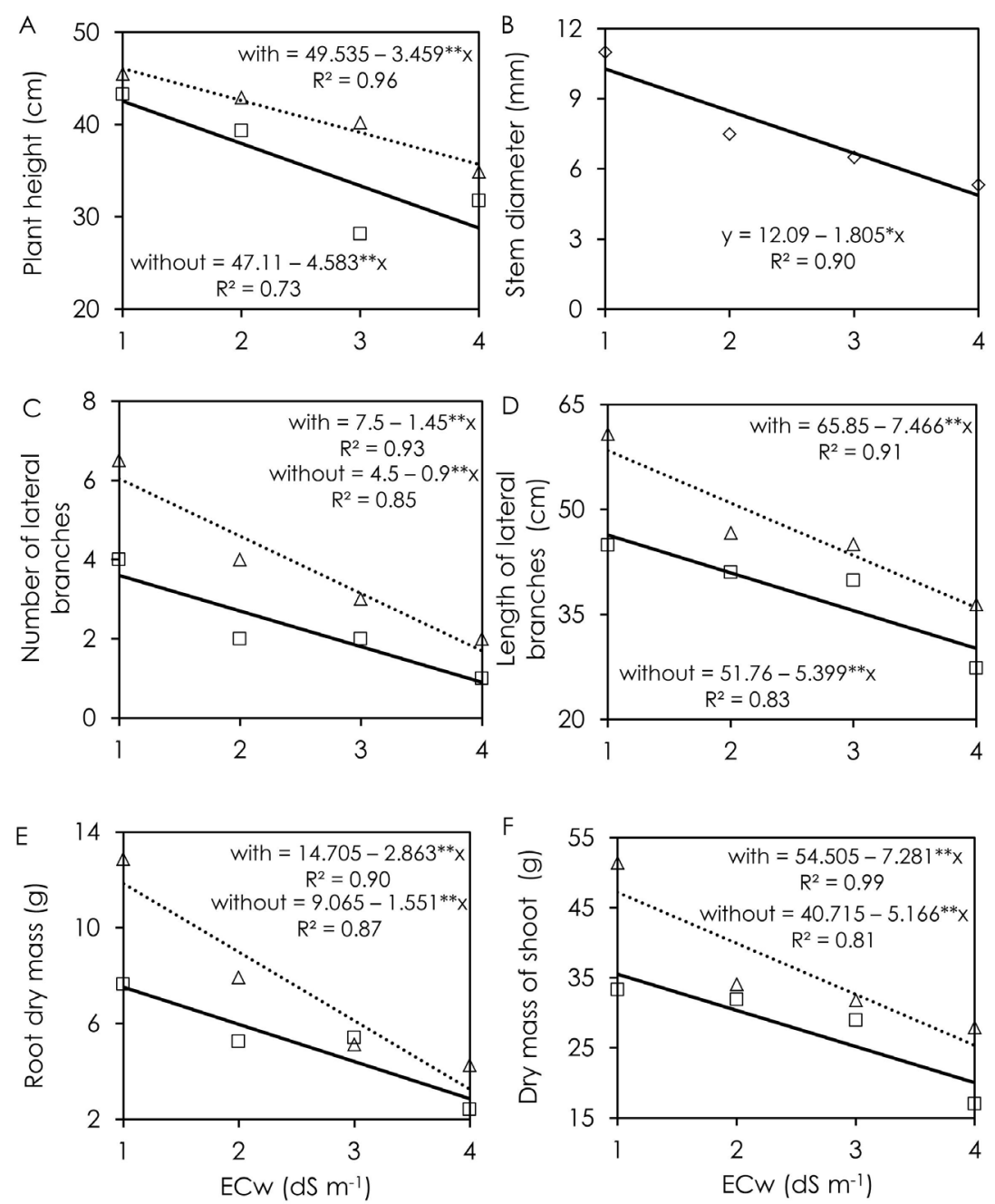

Figure 1. Plant height (A), stem diameter (B), number of lateral branches (C), length of latera branches (D), root dry mass (E) and dry mass of shoot cowpea irrigated with saline waters in the soil with and without bovine biofertilizer. $\Delta$ With and $\square$ Without biofertilizer 
In the cultivation of cowpea under saline irrigation, the reduction of dry matter of the aerial part occurs due to the deviation of energy due to the increase of soil salinity levels, since there is a greater energy expenditure by the plant (Lacerda et al., 2011). The effect of salinity on the dry mass of the aerial part of cowpea has been reported by several authors (Silva et al., 2011; Oliveira et al., 2013).

The authors observed that the increase in salinity of irrigation water reduced the growth of the bean plants expressed by the dry matter of the aerial part. Possibly, what may have caused this decrease in dry root and air mass accumulation was the inhibition of growth due to the toxic effects caused by the salts absorbed by the plants, the low osmotic adjustment capacity of the crop and the reduction of the total potential of the water caused by the increase in saline concentration (Silva et al., 2011; Oliveira et al., 2013; Çiftçi et al., 2011; Almeida et al., 2012; Calvet et al., 2013).

For the number of leaves, it was observed that there was a significant response to the ECW factor and to the application of biofertilizer, with data presenting a better fit to the decreasing linear equation, in which the highest value of leaf number was obtained in the salinity of $1 \mathrm{dS}$ $\mathrm{m}^{-1}$ (36.18 leaves) decreasing from this electrical conductivity (Figure 2A). Corroborating Silva et al. (2009), Coelho et al. (2013) in cowpea cv. Pele de moça and Calvet et al. (2014) in cowpea cv. EPACE 10, observed that the number of leaves was negatively affected by salinity.

The application of biofertilizer positively influenced the number of leaves of cowpea, presenting a maximum value of 31.68 leaves (Figure 2B). Possibly the biofertilizer attenuated the harmful effects of salinity on plants because the organic input stimulates the proliferation of microorganisms and solubilizers of essential nutrients in the soil, increasing their availability to plants (Sousa et al., 2013).

For the total dry mass (Figure 2C), the decline was expressive according to the increase in ECa, where the data were adjusted to a linear regression, reaching minimum values of $127.06 \mathrm{~g}$ when the plants were irrigated with ECW water of $4 \mathrm{dS} \mathrm{m}^{-1}$, while the initial level of $1 \mathrm{dS} \mathrm{m}^{-1}$ resulted in $184.95 \mathrm{~g}$. The application of bovine biofertilizer provided the highest values in the total dry matter, with a average of $162.76 \mathrm{~g}$ (Figure 2D).

In a study by Sousa et al. (2007) in cowpea cv. Pitiúba the authors verified that the total dry matter decreased linearly as the saline concentration of the irrigation water rose. Salinity may affect the total dry matter and nodulation production, which is justified by the toxic and nutritional effects in the root zone, affecting the net assimilation of $\mathrm{CO}_{2}$, inhibiting leaf expansion, reducing the photosynthetic area and, finally, the production of photo-assimilates (Neves et al., 2009a; Neves et al., 2009b).

The dry mass of the bean plant pod was significantly influenced by ECW (Figure 2E). The data were adjusted to the linear decreasing model, observing that as the salinity increased, there was an expressive reduction in the mass of cowpea beans, then the best result was obtained by irrigation with water ECW $1 \mathrm{dS} \mathrm{m}^{-1}$, obtaining a average of $8.26 \mathrm{~g}$. Reduction in dry mass of cowpea pod in response to the salinity was also observed by Bezerra et al. (2010).

The application of bovine biofertilizer positively influenced the dry mass of the pod, in which the highest average (7.66 g) was observed against $2.56 \mathrm{~g}$ obtained without the application of bovine biofertilizer (Figure 2F).

For the grain mass, there was a significant response only to the ECW factor, with data presenting a better fit to the linear equation. It was observed that the highest value of grain mass was obtained at the lowest level of ECW (1 $\mathrm{d} S \mathrm{~m}^{-1}$ ), decreasing from this saline level (Figure 2G). The application of bovine biofertilizer provided the highest values in the grain mass, with an average of $17.11 \mathrm{~g}$ (Figure 2B).

The dry matter of grains was significantly influenced by the effects of the interaction between the water salinity levels and the leaf application of bovine biofertilizer (Silva et al., 2013). Similar results were observed by Bezerra et al. (2010), who verified the occurrence of the reduction in the dry mass of cowpea beans in response to the salinity.

For the number of grain per pod, as the ECW increased, there was an expressive reduction, thus the best value was obtained in the 

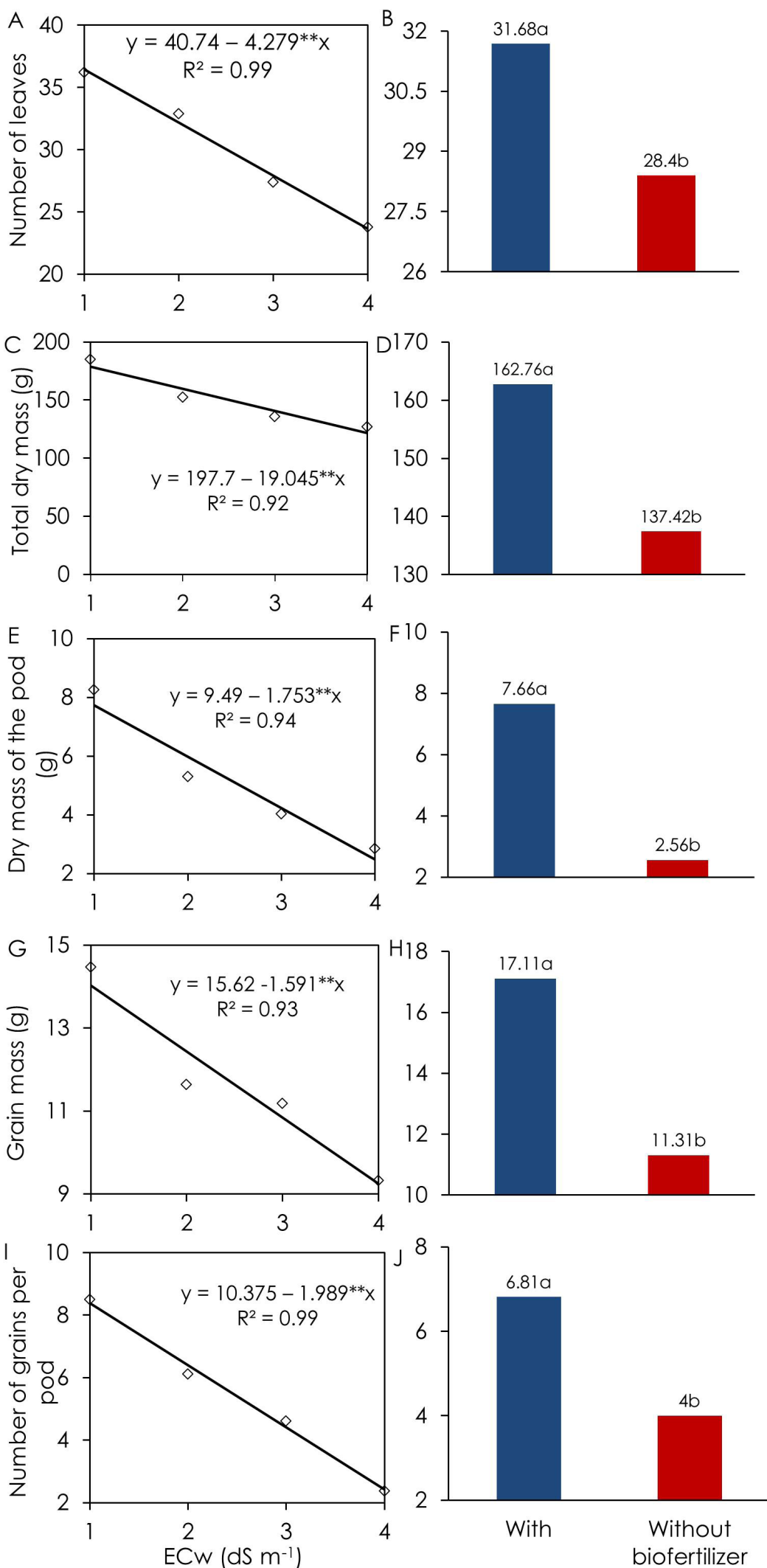

Figure 2. Number of leaves ( $A$ and $B$ ), total dry mass ( $C$ and $D$ ), dry mass of the pod ( $E$ and F), grain mass ( $G$ and $H$ ) and number of grains per pod (I and J) of cowpea irrigated with saline waters in the soil with and without bovine biofertilizer.

lowest ECW, with an average of 9.5 grains (Figure 21). In turn, the application of bovine biofertilizer resulted in the highest value obtained $(6.81 \mathrm{~g})$
(Figure 2J).

In a study developed by Assis Júnior et al. (2007) no effect of salinity on the number of 
grains per cowpea cV. EPACE 10 in response to salinity was observed. This same behavior was also observed by Oliveira et al. (2015) in cowpea cv. Carnaubais.

In the Figure 3A presents obtained results for the number of pods per plant as a function of the increase of salinity in irrigation water in cowpea plants treated with biofertilizer. There was a linear response to ECa increase, however, it was observed that the treatment with biofertilizer attenuated the effect of salt stress in the plants submitted to higher electrical conductivity 14 $\mathrm{dS} \mathrm{m}^{-1}$ ) obtaining the average of 6.5 pods with biofertilizer and 1.5 pods without biofertilizer.

Reduction in the number of pods per cowpea plant in response to salinity was also observed by Assis Júnior et al. (2007) in cowpea cV. EPACE 10, Bezerra et al. (2010) and Oliveira et al. (2015) in cv. Carnaubais.
A linear effect was observed for the number of grains per plant in response to the interaction of ECW with the biofertilizer. In each biofertilizer application conditions, the cowpea plants presented significance, whereas the best results were obtained in irrigation of $1 \mathrm{dS}$ $\mathrm{m}^{-1}$ corresponding to the maximum value of 61.5 grains per plant with the application of biofertilizer, while the ECW of $4 \mathrm{dS} \mathrm{m}^{-1}$ provided lower results of 19.36 grains per plant under application of biofertilizer (Figure 3B ).

Bean pod length was significantly influenced by ECW $x$ biofertilizer interaction expressing superiority in biofertilizer treatments (Figure 3C). It was found that as the ECw increased there was a reduction in pod length. Oliveira et al. (2015) also observed the occurrence of a reduction in the average length of pods of cowpea $\mathrm{cv}$. Carnaubais in response to salinity.
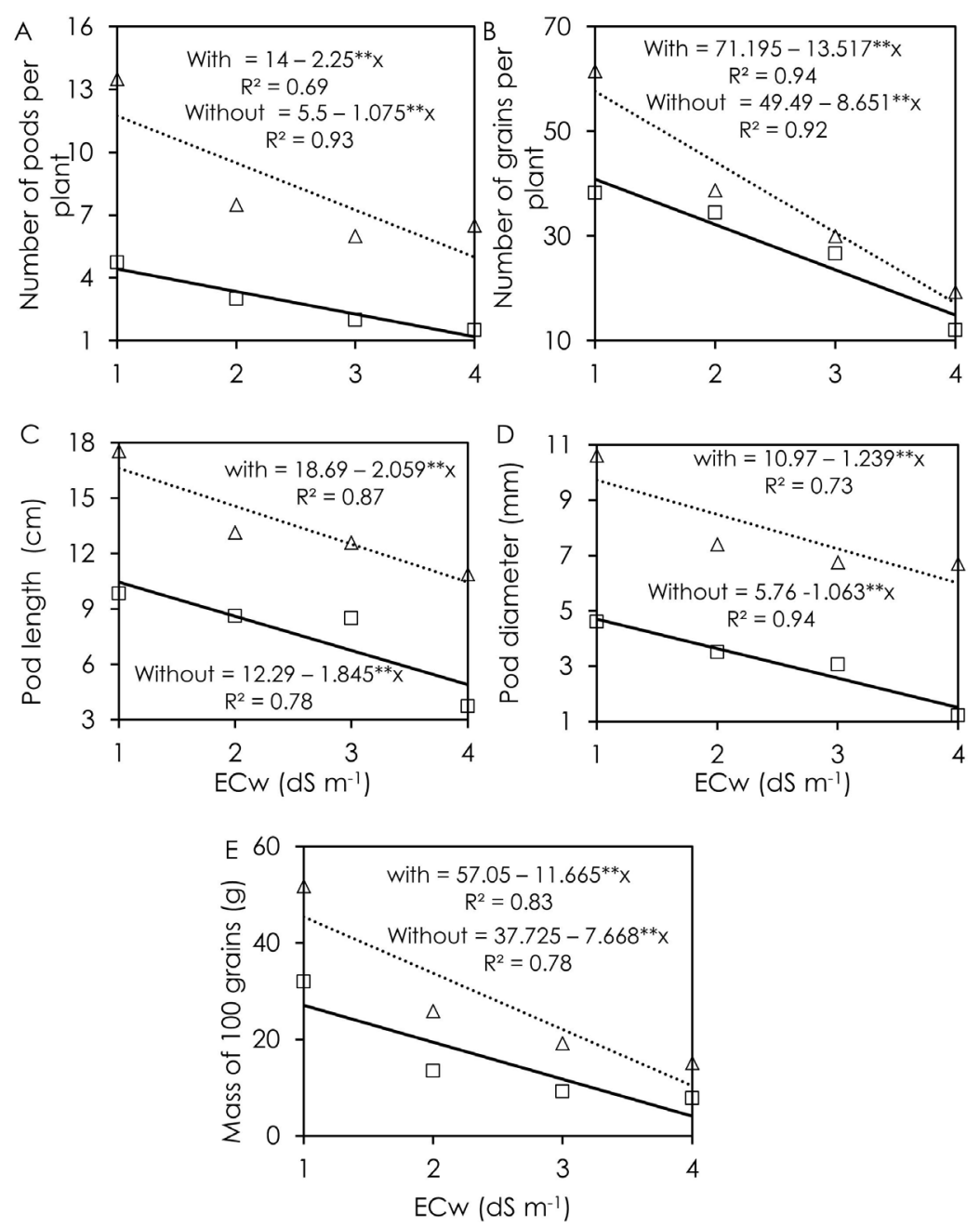

Figure 3. Number of pods per plant (A), number of grains per plant (B), pod length (C), pod diameter (D) and mass of 100 grains (E) of cowpea irrigated with salt water in the soil with and without bovine biofertilizer. $\Delta$ With and $\square$ Without biofertilizer 
Figure 3D presents the results obtained for the bean pod diameter as a function of the electrical conductivity of the water in plants treated with biofertilizer. It was verified that the data conformed to the linear model. When the plants were treated with biofertilizer, the highest values were obtained, obtaining maximum values of $10.62 \mathrm{~mm}$ in the lower electrical conductivity. In a study developed by Basso et al. (2012) the diameter of cowpea pods was negatively affected by salinity.

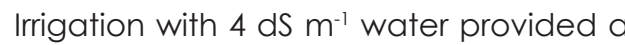
decrease according to its increase for the mass of 100 grains of cowpea plants, corresponding to a value of $14.99 \mathrm{~g}$ in the plants treated with biofertilizer, under irrigation with water of low ECW $\left(1 \mathrm{dS} \mathrm{m}^{-1}\right)$, and the plants presented higher results with an average of $51.66 \mathrm{~g}$ of grains. The quadratic regression model that best fit the data was the linear regression (Figure 3E).

Neves et al. (2009a), with the application of saline water of ECW equal to $5.0 \mathrm{dS} \mathrm{m}^{-1}$, verified that the salinity did not influence the mass of 100 cv. Epace 10.

\section{Conclusions}

The increase of ECW inhibits vegetative and productive growth of cowpea and the use of enriched bovine biofertilizer attenuates the effects of saline stress on cowpea, favoring its development.

\section{References}

Almeida, W. S. de, Fernandes, F. R., Bertini, C. H. D. M., Pinheiro, M. D. S., Teófilo, E. M. 2012. Emergência e vigor de plântulas de genótipos de feijão-caupi sob estresse salino. Revista Brasileira de Engenharia Agrícola e Ambiental 16: 10471054.

Assis Júnior, J. O., Lacerda, C. F., Silva, F. B. Silva, F. L. B., Bezerra, M. A., Gheyi, H. R. 2007. Produtividade do feijão-de-corda e acúmulo de sais no solo em função da fração de lixiviação e da salinidade da água de irrigação. Engenharia Agrícola 27: 702-713.

Basso, J. M., Takahashi, H. W., Fregonezi, G. A. F. 2012. Cultivo de feijão-vagem em vaso em diferentes substratos e condutividades elétricas da solução nutritiva. Semina: Ciências Agrárias 33: 2149-2162.

Bezerra, A. K. P., Lacerda, C. F., Hernandez, F. F. F., Silva, F. B., Gheyi, H. R. 2010. Rotação cultural feijão caupi/milho utilizando-se águas de salinidades diferentes. Ciência Rural 40: 10751082.

Calvet, A. S. F., Pinto, C. M., Lima, R. E. M., MaiaJoca, R. P. M., Bezerra, M. A. 2013. Crescimento e acumulação de solutos em feijão-caupi Irrigado com águas de salinidade crescente em diferentes fases de desenvolvimento. Irriga 18: 148-159.

Çiftçi, V., Tuerkmen, O., Dogan, Y., Erdin, C., Sensoy, S. 2011. Variation of salinity tolerance in bean genotypes. African Journal of Agricultural Research 6: 2394-2402.

Coelho, B., Barros, M. F. C., Bezerra Neto, E., Correa, M. M. 2013. Comportamento hídrico e crescimento do feijão vigna cultivado em solos salinizados. Revista Brasileira de Engenharia Agrícola e Ambiental 17: 379-385.

Ferreira, D. F. 201 1. Sisvar Versão 5.0. UFLA, Lavras, Brasil.

Freire, J. L. O., Cavalcante, L. F., Rebequi, A. M., Dias, T. J., Luna Souto, A. G. de. 2011 . Necessidade hídrica do maracujazeiro amarelo cultivado sob estresse salino, biofertilização e cobertura do solo. Revista Caatinga 24: 82-91.

Freire, A. L. O., Cavalcante, L. F., Rebequi, A. M., Dias, T. J., Brehm, M. A. S., Santos, J. B. 2014. Quality of yellow passion fruit juice with cultivation using different organic sources and saline water. Idesia 32: 79-87.

Freire, J. L. O., Cavalcante, L. F., Rebequi, A. M., Dias, T. J., Nunes, J. C., Cavalcante, Í. H. 2010. Atributos qualitativos do maracujá amarelo produzido com água salina, biofertilizante e cobertura morta no solo. Revista Brasileira de Ciências Agrárias 5: 102-110.

Hadi, F., Hussain, F., Arif, M. 2012. Growth performace e comparison of cowpea varieties under different $\mathrm{NaCl}$ salinity stresses. Greener Journal of Physical Sciences 2: 44- 49.

Lacerda, C. F., Sousa, G. G., Silva, F. L. B., Guimarães, F. V. A., Silva, G. L., Cavalcante, L. F. 2011. Soil salinization and maize and cowpea yield in the crop rotation system using saline waters. Engenharia Agrícola 31: 663-675.

Medeiros, R. F., Cavalcante, L. F., Mesquita, F. O., Rodrigues, R. M., Sousa, G. G., Diniz, A. A. 2011. Crescimento inicial do tomateiro-cereja sob irrigação com águas salinas em solo com biofertilizantes bovino. Revista Brasileira de Engenharia Agrícola e Ambiental 15: 505-511.

Neves, A. L. R., Lacerda, C. F., Guimarães, F. V. A., Hernandez, F. F. F., Silva, F. B., Prisco, J. T., Gheyi, H. R. 2009a. Acumulação de biomassa e 
extração de nutrientes por plantas de feijão-decorda irrigadas com água salina em diferentes estádios de desenvolvimento. Ciência Rural 39: 758-765

Neves, A. L. R., Guimarães, F. V. A., Lacerda, C. F. de, Silva, F. B. da, Silva, F. L. B. da. 2009b. Tamanho e composição mineral de sementes de feijão-de-corda irrigado com água salina. Revista Ciência Agronômica 39: 569-574.

Oliveira, F. D. A. de, Medeiros, J. F. de, Alves, R. D. C., Lima, L. A., Santos, S. T. dos, Lúcia, R. D. L. 2015. Produção de feijão caupi em função da salinidade e regulador de crescimento. Revista Brasileira de Engenharia Agrícola e Ambiental 19: 1049-1056.

Oliveira, F. D. A. de, Medeiros, J. F. de, Oliveira, M. K. de, Souza, A. A., Ferreira, J. A., Souza, M. S. 2013. Interação entre salinidade e bioestimulante na cultura do feijão caupi. Revista Brasileira de Engenharia Agrícola e Ambiental 17: 465-471.

Pereira, M. R. R., Martins, C. C., Souza, G. S. F., Martins, D. 2012. Influência do estresse hídrico e salino na germinação de Urochloa decumbens e Urochloa ruziziensis. Bioscience Journal 28: $537-$ 545.

Rhoades, J. D., Kandiah, A., Mashali, A. M. Uso de águas salinas para produção agrícola. 2000. UFPB, Campina Grande, Brasil. 117p.

Silva, F. E. O. da, Maracajá, P. B., Medeiros, J. F. de, Oliveira, F. de A., Oliveira, M. K. T. de. 2009. Desenvolvimento vegetativo do feijão caupi irrigado com água salina em casa de vegetação. Revista Caatinga 22: 156-159.

Silva, F. L. B., Lacerda, C. F. de, Neves, A. L. R., Sousa, G. G., Sousa, C. H. C., Ferreira, F. J. 2013. Irrigação com águas salinas e uso de biofertilizante bovino nas trocas gasosas e produtividade de feijão-decorda. Irriga 18: 304-317.

Silva, F. L. B., Lacerda, C. F., Sousa, G. G., Neves, A. L. R., Silva, G. L., Sousa, C. H. C. 2011 . Interação entre salinidade e biofertilizante bovino na cultura do feijão-de-corda. Revista Brasileira de Engenharia Agrícola e Ambiental 15: 383-389.

Sousa, G. G., Marinho, A. B., Albuquerque, A. H. P., Viana, T. V. A., Azevedo, B. M. 2012. Crescimento inicial do milho sob diferentes concentrações de biofertilizante bovino irrigado com águas salinas. Revista Ciência Agronômica 43: 237-245.

Sousa, G. G., Viana, T. V. A., Braga, E. S., Azevedo, B. M., Marinho, A. B., Borges, F. R. M. 2013. Fertirrigação com biofertilizante bovino: efeitos no crescimento, trocas gasosas e na produtividade do pinhão-manso. Revista Brasileira de Ciências Agrárias 8: 503-509.
Sousa, R. A., Lacerda, C. F., Amaro Filho, J., Hernandez, F. F. F. 2007. Crescimento e nutrição mineral do feijão-de-corda em função da salinidade e da composição iônica da água de irrigação. Revista Brasileira de Ciências Agrárias 2: 75-82.

Teófilo, E. M., Dutra, S. A., Pitimbeira, J. B., Dias, F. T. C., Barbosa, F. S. 2008. Potencial fisiológicos de sementes de feijão caupi produzidas em duas regiões do estado do Ceará. Revista Ciência Agronômica 39: 443-448. 